\title{
AN UNEXPECTED AUDIENCE: MANNER MANUALS IN RENAISSANCE EUROPE
}

By Jonathan Leece

The best-selling book of the entire sixteenth century was not a historical text on the glory of the Roman Empire, or a translation of the work of some great ancient philosopher, or even the Bible itself. That honor belongs to a simple treatise published in 1530, by a Dutch clergyman, on the education of noblemen's sons in manners. Translated into twenty-two languages within the first decade of publication, On Civility in Children was the cultural phenomenon of the day; it was read by thousands-a seeming contradiction since the book was intended for the nobility, Europe's minority class. ${ }^{1}$ By looking at the changing class structure of Renaissance Europe through the lens of Thorstein Veblen's theory of the "leisure class," one can see that there is no contradiction. Instead, the treatise was a logical best seller because the rising merchant class viewed manners as a way to emulate the practices of the ruling class during the early sixteenth century without sacrificing what had provided them with their wealth.

\footnotetext{
${ }^{1}$ Harry Mount, review of $A$ Handbook on Good Manners for Children: De Civilitate Morum Puerilium Libellus by Desiderius Erasmus, The Times, October 30, 2008, http://entertainment. timesonline.co.uk/tol/arts_and_entertainment/books/non-fiction/article5049916.ece (accessed May 1, 2010).
} 
During the late twentieth century, scholarship began to shift towards examining the changing social structure of the Renaissance and exploring the ways classes were distinguished from one another. This is exemplified in Norbert Elias's work The Civilizing Process: the History of Manners where he claims a major accomplishment of Erasmus's On Civility in Children was the development of the concept of civilité. ${ }^{2} \mathrm{He}$ describes how the immense popularity of On Civility in Children caused much of the importance attributed to the idea today. Norbert's assertion was a shift from the works of mid-twentieth century scholars, such as Ferdinand Schevil, who claimed the development of individualism, which came from the economic realm, defined the Renaissance. ${ }^{3}$ His argument could not pick out differences between the upper classes, since it treated political leaders and the emerging merchant class as the same. However, through careful examination of Erasmus's work, Elias found differences between the classes of the period. He pointed to Erasmus's advice to the nobility not to immediately put one's hands into the food as soon as they are seated, describing it as the actions of "wolves or gluttons." 4 In addition, Elias made the important insight that Erasmus's target audience for the treatise was noble boys and the sons of princes. ${ }^{5}$

More recently, Melanie White examined civilité in regard specifically to its importance within the classes of society around the time Erasmus published On Civility in Children. She argued that "as social pressures generated by increased literacy rates, heightened urbanization and the rise of capitalism intensified, a new conception of civility and civil society emerged." Shifting from the previous emphasis on the differences between civil and barbarian, the concept of civility evolved to become a scale to distinguish between individuals within a "civil" society. Civility was "standardized," with markers such as "politeness, decorum, courtesy or good manners," which allowed the upper classes to distinguish themselves from other classes based on an examination of each group's level of civility. ${ }^{7}$ However, using civility as a measuring stick

\footnotetext{
${ }^{2}$ Norbert Elias, The Civilizing Process: The History of Manners, trans. Edmund Jephcott (New York: Urizen Books, 1978), 53.

${ }^{3}$ Ferdinand Schevil, "The Society of the Italian Renaissance," in The Civilization of the Renaissance (New York: Frederick Ungar Publishing, 1959), 54.

${ }^{4}$ Elias, 57.

${ }^{5}$ Ibid., 55.

${ }^{6}$ Melanie White, "An Ambivalent Civility," The Canadian Journal of Sociology 31, no. 4 (Autumn 2006): 446.

${ }^{7}$ Ibid., 447.
} 
faltered when the manual, written for the few, was acquired by the masses. If the masses could access the means to learn about civility, this conceived notion would fail as an accurate distinguishing factor between the classes.

During the late Medieval period, changes in the balance of power led to the emergence of the noble class, which was the target audience for On Civility in Children. Beginning with Marsilius of Padua's Defensor Pacis, written in the fourteenth century, an increasing number of assertions held that, within the state, power must be united in one person, the prince. ${ }^{8}$ The central claim of Padua's work is that the interference of papal government in secular life posed a danger to "human happiness, as experienced in the peaceful and selfsufficient community." This shift in the way intellectuals of the time thought about government allowed secular monarchs to take greater power-moving against the traditional limits that custom had previously imposed upon them. ${ }^{10}$ Economic and demographic crises, such as the reduction of the labor market caused by the plague, allowed these secular governments to assume ever-increasing control over their subjects, including the infant merchant class, embodied at that time by the moneylenders. Despised because of their profession, some even viewed these moneylenders as an affront to God. ${ }^{11}$ The Church from its earliest days had forbid the practice of usury and many rulers felt they could infringe, with God's authority, upon these men in order to increase their own power. These intellectual and economic trends began to coalesce as the Medieval period ended and the eventual replacement of religious rulers by secular authorities marked one of the key shifts as Europe entered the Renaissance. ${ }^{12}$

However, throughout the Renaissance, the secular princes themselves slowly began to lose their power to the economic elites who controlled vast fortunes. These merchant elites were capable of controlling thousands of people due to their increasing use of offering loans with required interest payments;

${ }^{8}$ Harry A. Miskimin, The Economy of Early Renaissance Europe: 1300-1460 (Englewood Cliffs: Prentice-Hall, 1969), 167.

${ }^{9}$ Cary J. Nederman, "Nature, Justice, and Duty in the Defensor Pacis: Marsiglio of Padua's Ciceronian Impulse," Political Theory 18, no. 4 (November 1990): 617.

${ }^{10}$ Miskimin, 167.

${ }^{11}$ E R. Chamberlin, Everyday Life in Renaissance Times (New York: Capricorn Books, 1967), 67.

${ }^{12}$ Miskimin, 170. 
the social taboos against usury were disintegrating. ${ }^{13} \mathrm{With}$ the greater fortunes amassed during the Renaissance and the ability to call upon such wealth at any of the major trade centers of Europe, merchants even had a degree of power over who would rule the nations. No longer could kings demand aid from the despised moneylenders and ignore their obligations if they so desired. ${ }^{14}$ For example, the Hansa family backed the ascension of Edward IV to the throne of England, while two other merchant families, the Fuggers and Welsers, bought, in essence, the electoral votes that made Charles V Holy Roman Emperor. Merchants continued to make loans, but now they had the power to demand trading privileges that princes had to respect. The French historian Lucien Febvre described them as "[men] of swift decision, of unusual physical and moral energy, of an unrivalled boldness and determination." ${ }^{15}$ In this way, these merchants sound much like the soldiers who made themselves kings during the Middle Ages. In fact, by the sixteenth century, outwardly there was little to distinguish the wealthy merchant class from the ruling class. ${ }^{16}$

Focusing on the defining elements of the upper classes of society in his 1889 book, The Theory of the Leisure Class, Thorstein Veblen offered an early critique of consumerism, which he asserted could be traced back to prehistory. He argued that society's notions of goods or positions drive economics rather than the utility they offer. This ultimately leads to the development of a ruling-leisure-class who only contributed to society in a small measure, yet held positions of power over the rest. He did not believe the leisure class was devoid of incentive toward action, but claimed it "is so greatly qualified by the secondary demands of pecuniary emulation" the most imperative of which was "the requirement of abstention from productive work." ${ }^{17}$ In this way, Veblen characterized the leisure class by their actions and the pursuit of things that have no economic value merely to raise their status in society. However, it is not enough for the members of this class to simply possess wealth or power,

\footnotetext{
${ }^{13}$ V.H.H. Green, Renaissance and Reformation: A Survey of European History between 1450 and 1660 (New York: St Martin's Press, 1964), 22.

${ }^{14}$ Chamberlin, 63.

${ }^{15}$ As quoted by J.R. Hale, Renaissance Europe: Individual and Society, 1480-1520 (New York: Harper \& Row, 1971), 144.

${ }^{16}$ Chamberlin, 63

${ }^{17}$ Thorstein Veblen, The Theory of the Leisure Class (New York: The MacMillan Company, 1912), 36.

${ }^{18} \mathrm{Ibid}$
} 
but it "must be put in evidence, for esteem is awarded only in evidence." 18 The waste of one's time in the pursuit of nonproductive actions, which Veblen called "conspicuous leisure," would include the "need" for education in civility - a concept central to Erasmus's work.

Desiderius Erasmus was a Dutch humanist, Catholic priest, and theologian who wrote On Civility in Children in $1530 .{ }^{19}$ The book purposed to convince its readers "that chyldren euen strayt fró their infancie should be well and gently broughte vp in learnynge." ${ }^{20}$ Written specifically for the education of young boys of noble birth, Erasmus intended to bring attention to the need of education for the offspring of the rulers of the time. Erasmus, a man with little tolerance for the merchant class, claimed it was not natural "for money to breed money" and "would accept a usurer sooner than this sordid class of merchants who use tricks and falsehoods, fraud and misrepresentation, in pursuit of profit from any source." 21

In his handbook, Erasmus wrote as though education is something that is not only necessary, but also all but commanded by nature. Writing "nothynge doth better occupy $y^{\mathrm{e}}$ whole mynd of man, the studies," and that the "chyefe of all mans felicitye, [is] to be good instruccion, \& right bryngynge vp," he asserted that training a child to pursue knowledge should be a major part of their upbringing. ${ }^{22}$ Furthermore, he implied that education is the greatest part of building upon the gift of reason given to mankind. Erasmus compared this gift to those given by nature to other creatures, such as flight, scales, horns, and venom and concludes that a "mynde hable to receiue all discipline" supersedes all these, if a man will use it. ${ }^{23}$ However, looking back, it seems obvious that Erasmus would have to set this down before his readers as something unquestionably true. His strong convictions about the impor-

${ }^{18}$ Ibid.

19 When reading quotations from Erasmus, keep the following in mind: $\mathrm{v}$ and $\mathrm{u}$ are interchangeable; the - over a vowel is either $-\mathrm{m}$ or $-\mathrm{n}$; ye $=$ the; $\mathrm{yt}=$ that; and y's are very often used instead of i's

${ }^{20}$ Desiderius Erasmus, The Education of Children, in A Treatise of Schemes and Tropes, trans. Richard Sherry (1550), http://www.gutenberg.org/ files/28338/28338-h/28338-h.htm (accessed April 25, 2010).

${ }^{21}$ Desiderius Erasmus, The Adages of Erasmus, ed. William Barker, trans. Margaret Mann Phillips (Toronto: University of Toronto Press, 2001), 120.

${ }^{22}$ Erasmus, The Education of Children.

23 Ibid 
tance education led him to write On Civility in Children and he would have to portray it to his readers as something desirable if he hoped to influence their thoughts on the matter.

Erasmus recognized the argument that the education process should wait until children were older posed the strongest opposition to his push for the development of the mind. The way Erasmus dealt with this argument makes it seem like the method of waiting and only teaching older children was a common practice, probably just as frequently employed as the timetable Erasmus proposed. He urged parents not to squander the first years of their children's lives by refusing them any form of instruction during that time. If they did, Erasmus warned that when they got around to giving their children an education their "age wyll not so well be handled, and hys wytte shall be more readye to euyll, and peraduenture possessed alreadye $\mathrm{w}^{\mathrm{t}}$ the fast holdyng bryers of vices." ${ }^{24}$ In this way, Erasmus showed that putting off teaching would only hamper their children's education when they finally did undertake it. Rather, he argued, education should begin early in order to preempt the development of bad habits.

In addition to the vices that grow as a child ages and is exposed to the world, the observation is made that things are learned more easily by the young than the old. This point seems to be put forward more strongly than the others; "Care not thou for those fooles wordes which chatter that thys age, partly is not hable inough to receiue discipline, \& partlye vnmete to abyde the labours of studies." 25 By calling those who argue differently than he "fools," Erasmus used his own status as a renowned scholar and humanist to discredit them and their ideas. In addition to dismissing the opposite point of view, examples are employed to show how the ability for youth to learn is a universal truth. He asks his readers rhetorically about the process of training an animal, knowing that it begins when the animal is still young so that it might remember its training. Erasmus even compares it to horticulture asking, "Do they not teach euen straight way the plâtes whyle they be yet tender, to put awaye theyr wylde nature by graffynge, and wyll not tarye tyll they be waxen bygge and myghtye?" 26 Thus it is made clear to the reader that in all ways it is

\footnotetext{
${ }^{24}$ Ibid.

${ }^{25}$ Erasmus, The Education of Children.

${ }^{26}$ Ibid.
} 
better to begin the process of teaching at a young age, rather than to wait and put it off for several years.

Despite the probability that On Civility in Children was read by more than its intended audience, the methods Erasmus supports severely limited the number of people who could have taken his advice. Although he warns his reader "not to suffer after the iudgemente and example of the cómon people," the warning is not stated simply because they are commoners, but because of the way they go about raising their children. ${ }^{27}$ It is here that the Erasmus meets Thorstein Veblen's theory of the leisure class and of conspicuous leisure. During this time period, the new ruling families and wealthy merchants of Europe acquired the privileges that were once held only by the nobility of the Middle Ages. One of the best ways to determine the status of a person was whether or not they or their children had to work. One of the unspoken assumptions of On Civility in Children is that the parents of the child in question can afford to not only be absent from the house and any jobs they may need to do, but also that the family can pay for someone to instruct their child. The idea that the parents should not "let go any parte of hys [the child's] tyme vnoccupied" assumes that were their child not given an education, they would otherwise be doing nothing. ${ }^{28}$ This is also a physical way of showing off to others that one is wealthy enough not to work. When one knows all the proper etiquette and manners of court, as well as knowledge of other subjects, it is obvious that they have spent time studying-time that would have been spent working were it necessary for the family.

Looking at Erasmus's work in this manner, it supports Thorstein Veblen's theory of conspicuous leisure. Although he never writes of how education can be used to show off one's status to men, he assumes his readers have sufficient time and money to have their children study rather than work to produce something of economic value. This particular ideology is a clear example of Veblen's theory of conspicuous leisure. Because of this notion, it is obvious that the only people who could afford to follow the guidelines laid out by Erasmus would be the leisure class who proved their status by spending their children's time on education.

\footnotetext{
${ }^{27}$ Ibid.

${ }^{28}$ Erasmus, The Education of Children.
} 
While Erasmus wrote for those already established in the leisure class, the ruling nobles, his audience widened with the growing wealthy merchant class. Veblen's theory of the leisure class applies even more when the changing nature of the classes is examined from the late Medieval period to the Renaissance. With the early shift towards capitalism during the Renaissance, merchants attained much greater economic power. This marked the rise of a consumer culture where merchants began to take some of the power from the former rulers and, in some cases, took the reigns of governing themselves. ${ }^{29}$ Although Erasmus makes it clear his purpose is to help the education of the sons of royalty and the nobility, his suggestions can be followed by any who have the means to keep their sons from work during their childhood. "Comonly the rycher that men be, the lesse they care for the bryngyng vp of their chyldren." ${ }^{30}$ Here Erasmus only mentions a man's wealth as a reason for this attitude. Because of this, the merchants who began to amass great fortunes during the Renaissance could just as easily have taken his advice. Therefore, when looking at Erasmus's On Civility in Children, there is no contradiction between the outstanding number of sales and the relatively small target audience of noblemen for whom Erasmus himself wrote.

Furthermore, as Renaissance merchants, and their sons, began to siphon power for themselves, they fell into the category of rulers that Erasmus was writing for and looked for ways to imitate the established portions of the upper class. Having been under the nobles for so long, they would naturally be inclined to assume the practices they associated with the powerful. ${ }^{31}$ In addition, having worked their way up the social ladder, these merchants would be more willing to work to build their power and prestige. ${ }^{32}$ Despite Erasmus's intense dislike of the merchant class in Europe, these men constituted more of his readership since they greatly outnumbered the nobility and saw the manual as an easy way to associate with the noble elite.

The portrait of Georg Giese, painted by Hans Holbein the Younger in 1532, exemplifies the steps the merchant class took to imitate the ruling class.

${ }^{29}$ Chamberlin,63.

${ }^{30}$ Erasmus, The Education of Children.

${ }^{31}$ Norbert Elias, On Civilization, Power, and Knowledge, ed. Stephen Mennell and Johan Goudsblom (Chicago: The University of Chicago Press, 1998), 67.

${ }^{32}$ Ibid., 68. 
The simple fact that this painting, in addition to many others, exists is evidence of the shift in attitude of the merchant class. ${ }^{33}$ Portraits gave prestige to those who commissioned them; a concept carried over from a time when only royalty had the capability to have them made. During the Renaissance, however, painters increasingly began painting portraits for wealthy merchants who wished to show off their status. Georg Giese's portrait showed a welldressed man surrounded by fine things, including a container filled with gold coins. Books and letters with different seals showed the man was not only educated, but also had contact with various people from different locations. ${ }^{34}$ The commissioning of portraits as proof of their status indicates that wealthy merchants were quickly becoming members of the leisure class. However, they sought to affirm this by mimicking those already in power, evidenced by the sales of pamphlets meant for the nobility, such as On Civility in Children.

Despite this desire for association with the rulers of the period, the merchant class would not give up what had given them upward mobility. In 1528, two years before On Civility in Children was published, Baldassare Castiglione published The Book of the Courtier to instruct his readers on what constituted the perfect courtier. Unlike Erasmus, he wrote his dialogue not just for the nobility, but all the upper classes. ${ }^{35}$ This raises an apparent dilemma in that the book written exclusively for the nobility outsold the one meant for a broader audience. However, by looking closer at The Book of the Courtier, the explanation for this is clear. Reception for Castiglione's work was warm, especially from the nobility of Italy. He included things for everyone among the upper class, and referred specifically to individuals he knew personally from his time at the court of Urbino during the first decade of the sixteenth century. ${ }^{36}$ However, despite parts that could be applied by the upwardly mobile merchant class, it was less popular among such men. This is probably due to Castiglione's description of the perfect courtier as a whole; especially the parts

${ }^{33}$ Jan Gossaert, Portrait of a Banker, 1533, The National Gallery of Art, Washington, DC.; Marinus Claesz, The Moneychanger and his Wife, 1539, Museo del Prado, Madrid; Quentin Matsys, The Moneylender and his Wife, 1514, Musée du Louvre, Paris.

${ }^{34}$ Hans Holbein the Younger, Portrait of the Merchant Georg Gisz, 1532, Berlin State Museums.

${ }^{35}$ Peter Burke, The Fortunes of the Courtier (University Park: The Pennsylvania State University Press, 1996), 48.

${ }^{36}$ Ibid., 47. 
antithetical to the way merchants had become powerful. Specifically, he held fast to the notion that the profession of the perfect courtier should be that of arms. ${ }^{37}$ Castiglione affirmed this position again when the discussion in the book moved toward the practice of letters, which better aligns with the merchant's vocation. In response to the necessity for the courtier to wholly engage in the "ornament of arms," the speaker jests that in "a contest wherein he who defends the cause of arms is allowed to use arms, just as those who defend letters make use of letters in their defence; for if everyone avails himself of his proper weapons, you shall see that men of letters will be worsted." 38 These jests at the way of life for merchants would have upset some and probably was one reason The Book of the Courtier was outdone by Erasmus's work. This shows that while the rising merchant class wished to emulate the rulers of the day, they were less impressed with works that failed to appreciate the means that had raised them to a position of power.

Other instructional manuals written for the nobility during the time also failed to generate the same level of success Erasmus enjoyed. One of the most prominent of these is Niccolò Machiavelli's The Prince, which was published posthumously in 1532. Initially very popular, the manual quickly fell into disfavor, placed on the Papal Index of Prohibited Books a mere twentyseven years after its publication. ${ }^{39}$ While this is a major reason for the small numbers of copies sold, the subject material would also have affected sales to the merchant class. Seen vaguely in Castiglione's work, the themes of Machiavelli were specific to those who controlled the government. Despite the fact that merchant families, such as the Medicis of Florence, did rise to the position of ruler, most were not concerned with "the different kinds of militia and mercenary soldiers" or "the way to govern cities or dominions that, previous to being occupied, lived under their own laws." ${ }^{40}$ This explains why some instructional manuals, while written to instruct nobles on issues of the nobil-

${ }^{37}$ Baldassare Castiglione, The Book of the Courtier, trans. Leonard Opdycke, (Mineola: Dover Publications, 2003), 25.

${ }^{38}$ Ibid., 60.

39 “Niccolò Machiavelli, 1469-1527," Enotes Literary Criticism, http://www.enotes.com/ literary-criticism/machiavelli-nicollo (accessed June 6, 2010).

${ }^{40}$ Niccolò Machiavelli, The Prince, ed. E. R. P. Vincent, trans. Luigi Ricci, (New York: The Oxford University Press, 2008) 21, 50. 
ity, were not bought in great numbers by the merchant class who wished to imitate the nobility to show their status.

Therefore, the explanation for the great success of Erasmus's On Civility in Children lies in the changing class structure in Renaissance Europe. As the status of merchants and moneylenders grew, they sought to display this by emulating the ways of those who already held power. This included purchasing instructional manuals such as On Civility in Children and commissioning portraits such as Hans Holbein the Younger's painting of Georg Giese. These actions are obviously "qualified by the secondary demands of pecuniary emulation," with the sole purpose of presenting themselves as above the requirement for productive work. ${ }^{41}$ However, they did not forgo that which had given them power and thus disregarded manuals such as The Book of the Courtier and The Prince. Rather, we see a slight shift in the make-up of the upper class as the emerging merchant class sought to take on many of the trappings of the already established ruling class, such as the manners and etiquette taught by Erasmus's On Civility in Children, but also held fast to their merchant roots, which had brought them to the highest stratum of society.

${ }^{41}$ Veblen, 36. 
Burke, Peter. The Fortunes of the Courtier. University Park: The Pennsylvania State University Press, 1996.

Castiglione, Baldassare. The Book of the Courtier. Translated by Leonard Opdycke. Mineola: Dover Publications, 2003.

Chamberlin, E R. Everyday Life in Renaissance Times. New York: Capricorn Books, 1967.

Elias, Norbert. On Civilization, Power, and Knowledge. Edited by Stephen Mennell and Johan Goudsblom. Chicago: The University of Chicago Press, 1998.

The Civilizing Process: The History of Manners. Translated by Edmund Jephcott. New York: Urizen Books, 1978.

Erasmus, Desiderius. The Adages of Erasmus. Edited by William Barker. Translated by Margaret Mann Phillips. Toronto: University of Toronto Press, 2001.

. The Education of Children. In A Treatise of Schemes and Tropes. Translated by Richard Sherry. 1550. http://www.gutenberg.org/files/28338/ 28338-h/28338-h.htm (accessed April 25, 2010).

Green, V H H. Renaissance and Reformation: A Survey of European History between 1450 and 1660. New York: St Martin's Press, 1964.

Hale, J.R. Renaissance Europe: Individual and Society, 1480-1520. New York: Harper \& Row, 1971.

Machiavelli, Niccolò. The Prince. Edited by E. R. P. Vincent. Translated by Luigi Ricci. New York: The Oxford University Press, 2008.

Miskimin, Harry A. The Economy of Early Renaissance Europe: 1300-1460. Englewood Cliffs: Prentice-Hall, 1969.

Mount, Harry. Review of A Handbook on Good Manners for Children: De Civilitate Morum Puerilium Libellus by Desiderius Erasmus. The Times, October 30, 2008. http://entertainment.timesonline.co.uk/tol/arts_and_entertainment/books/ non-fiction/article5049916.ece (accessed May 1, 2010). 
Nederman, Cary J. "Nature, Justice, and Duty in the Defensor Pacis: Marsiglio of Padua's Ciceronian Impulse.” Political Theory 18, no. 4 (November 1990): 615-637.

“Niccolò Machiavelli, 1469-1527.” Enotes Literary Criticism. http://www.enotes. com/literary-criticism/machiavelli-nicollo (accessed June 6, 2010).

Schevill, Ferdinand. "The Society of the Italian Renaissance." In The Civilization of the Renaissance. New York: Frederick Ungar Publishing, 1959.

Veblen, Thorstein. The Theory of the Leisure Class. New York: The MacMillan Company, 1912.

White, Melanie. "An Ambivalent Civility." The Canadian Journal of Sociology 31, no. 4 (Autumn 2006): 445-460. 